\title{
Human wellbeing and automotive industry: correlations in the era of economical digitalization
}

\author{
Egor Dudukalov ${ }^{1}$, Muhammad Imtiaz Subhani ${ }^{2}$, and Denis Ushakov ${ }^{3, *}$ \\ ${ }^{1}$ Russian Presidential Academy of National Economy and Public Administration, South institute \\ of Management, Pushkinskaya, 70, Rostov-on-Don 344007, Russia \\ ${ }^{2}$ ILMA University, Main Ibrahim Hyderi Road, Korangi Creek, Karachi, Pakistan \\ ${ }^{3}$ Suan Sunandha Rajabhat University, 1 U-Thong Nok rd., Dusit, Bangkok, 10300, Thailand
}

\begin{abstract}
This research studies the relation between human wellbeing and automotive industry, as to whether the performance of automobile industry translates to an overall well-being of the populace. The study is based on secondary-data, and mainly takes into account the Prosperity-Index / ranking and its possible linkage with automotive sale volume of the nations. Findings of this study confirms that that the higher the prosperity index or ranking, the higher the automotive sales volume for most of the nations but several factor should be taken in to consideration, for example India automotive sale volume is bigger than the automotive sales volume of France but France prosperity rank is 19 and India in on 88 rank, it is because of the size and population of the country, India might have 10 times more population than France when divided among the population France may investing much more than India on their citizen. Findings reveal that Canada leads the table on first position with Australia on second position in the prosperity ranking, due to they provide enough opportunities for their people to live a good and healthy lives and these can be observed in terms of good automotive sales volume by these two nations. Further, finding also reveals that the automotive sales number of United States of America or several other countries have large value but that does not mean that they are also good in ranking in Prosperity Index which implies that the prosperity ranks has no direct relation with the automotive sales volume that a country generates.
\end{abstract}

\section{Introduction}

The trends of increasing quality of life and living standards has now become something that the world expects more of as we enter globalization and a technological-era which heavily relies on robotics. This study focuses on the contributions of automobile industry in the growth of human-wellbeing all across the world, and how automobile industry has staggeringly changed the human lifestyle and quality-of-life over the decades.

\footnotetext{
* Corresponding author: denis.us@ssru.ac.th
} 
Thus the question arises, is human-wellbeing translatable from developments in the automobile-industry? The first question that comes to our mind is what is wellbeing? Wellbeing is often defined as a state of health, happiness, and prosperity; in other words, it means living an overall healthy and satisfied life.

Human-being, perhaps out of their own self-interest, explore the potentialities of both the self and the society, in-order to lead a happy and prosperous life. The Legatum Prosperity Index was taken due to the same consideration, since it's the only index that measures not only the prosperity factors but also the well-being factors [1].

The primary objective of this research is to find out the impact on human wellbeing as brought about by automobile-industry. Today the automobile-industry in one of largest revenue generating industries, and people are willing to pay anything for their desired vehicle, partly to own a status-symbol, and mostly for utility purposes. This study has conducted a detailed research, and aims to find as to what extent is the human-wellbeing brought about by the automobile-industry?

\section{Literature review}

Automobile-industry is perhaps the most innovative and one of the fastest leading industries of the world. Automobile-manufacturers have also relished the competitive advantage in their respective fields; according to Rugraff the competition in automobile industry has increased as with the rapid developments in the technology and technological methods [2]. It is furthermore also very important for an automobile organization to maintain healthy relation with the consumers, in-line with the effective and efficient methods that the company had decided on.

Automobile-industry has played a major part in increasing the status and quality of the human life and well being. Today the value and utility as brought about by a car can be well afforded by a person earning about \$2000 [2,3]. Moreover, people who lack ownership of a car, make struggles to improve their well-being and also attach connotations of passion to their struggles, often viewing cars as no longer just utility-machines or status-symbols, but also as symbols success and class-mobility.

Automobile-industry is furthermore the fastest growing industry in the world, and continues to grow by doubling every year. According to a survey, by 2020, there will be such a large number of cars on the roads, that vehicles will be more visible of a sight than pedestrians [4,5]. It is true that the automotive-industry has benefitted the consumers by providing value in terms of both utility and luxury, yet growth in automotive industry is essentially the reason why both the automobile consumers and producers work more inorder to earn and afford these factors of well-being for themselves and their families.

The nature of well-being has been extensively studied by marketers, as their job is to generate and provide value (which is the core constituent of well-being) [6,7]. Automobile marketers have very well targeted human well-being, and the competition amongst them has significantly risen up the automobile options in available in the markets. The marketers have also managed to attribute status and success to the automobile products, which has led people to judge a person's quality of life based on their car ownership of choice $[8,3]$.

Prosperity Index is (as developed by Legatum) is a well-regarded index which measures national prosperity and 142 countries based on: economy, education, health, governance, personal-freedom, entrepreneurship and opportunity, social-capital, and safety and security. Whereby it be clearly seen which countries rank high in prosperity, and specifically excel in which categories $[9,10]$.

Norway has so far been leading the list for the past seven years, with other Western and Northern European countries following along; as for 2016, Canada and Australia also hold the 6 th and 7 th positions. 
As of 2016, the index is based on 200+ variables that were analyzed for over 142 countries.

Table 1. Correlations between automotive sales and prosperity index.

\begin{tabular}{|c|c|c|}
\hline Countries & Automotive Sales Volume & $\begin{array}{l}\text { Prosperity index } \\
\text { (Overall Ranks) }\end{array}$ \\
\hline Canada & 786086.308 & 5 \\
\hline Australia & 586287.308 & 6 \\
\hline United States Of America & 6518678.615 & 10 \\
\hline Germany & 3298415.308 & 14 \\
\hline United Kingdom & 1965083.385 & 16 \\
\hline Japan & 4221548.000 & 18 \\
\hline France & 2153714.000 & 19 \\
\hline Taiwan & 211992.923 & 22 \\
\hline Spain & 188872.538 & 23 \\
\hline Czech Republic & 405621.462 & 26 \\
\hline South Korea & 1128793.308 & 27 \\
\hline Italy & 267625.538 & 29 \\
\hline Poland & 263474.769 & 30 \\
\hline Hungary & 318219.077 & 39 \\
\hline Argentina & 402811.308 & 42 \\
\hline Malaysia & 470706.077 & 44 \\
\hline Brazil & 2154689.462 & 47 \\
\hline China & 9585804.333 & 54 \\
\hline Mexico & 569158.308 & 55 \\
\hline Romania & 188872.538 & 57 \\
\hline Russia & 1965083.385 & 65 \\
\hline Indonesia & 508812.462 & 69 \\
\hline South Africa & 358439.308 & 70 \\
\hline Ukraine & 318219.077 & 71 \\
\hline Turkey & 405621.462 & 81 \\
\hline India & 1721036.308 & 88 \\
\hline Pakistan & 130425.000 & 123 \\
\hline
\end{tabular}

\section{Findings and results}

Below are the tables which explain empirically the automotive (cars) annual sales volume and prosperity index ranking of the outlined selected nations in comparison [10].

Above tables explained the prosperity ranking of 26 countries and the automotive annual sales volume of these same 26 nations. Findings reveal that the higher the prosperity index or ranking, the higher the automotive sales volume for most of the nations but several 
factor should be taken in to consideration, for example India automotive sale volume is bigger than the auto motive sales volume of France but France prosperity rank is 19 and India in on 88 rank, it is because of the size and population of the country, India might have 10 times more population than France when divided among the population France may investing much more than India on their citizen [11].

Canada leads the table on first position with Australia on second position in the prosperity ranking, due to they have very large land vacant and compared to the land have less population which enables them to provide enough resources for living to their citizens and also they are very good in controlling crime rate and provides enough opportunities for their people to live a good and healthy lives and these can be observed in terms of good automotive sales volume by these two nations.

Countries like Pakistan and India which are at lowest rank are those who have not been on a good scales at prosperity index. Increasing poverty, rate of unemployment, less budget on education and health less per capita income were the main reason that disturbed the prosperity index rating and also resulting automotive industry to not grow as it can be seen through a meager automotive sales volume in these countries [12].

Further, finding also reveals that the automotive sales number of United States of America or several other countries have large value but that does not mean that they are also good in ranking in Prosperity Index which implies that the prosperity ranks has no direct relation with the automotive sales volume that a country generates.

\section{Conclusion}

The basic findings show that all those countries which work for betterment of their citizens score good in prosperity index and as well as automotive sales volume but that does not mean that prosperity index of a nation has necessarily direct association with its automotive sale volume, that is a country with highest automotive sales volume does not show up the highest rank in prosperity index.

\section{References}

1. K. Atherton, Index project, Industrial and Commercial Training 13, 2, 48 - 53 (1981)

2. E. Rugraff, The new competitive advantage of automobile manufacturers, Journal of Strategy and Management (4), 407 - 419 (2012)

3. H.T. Van, A.T. Huu, D. Ushakov,. Liberal reforms \& economic growth: Current issues and interrelations. Journal of International Studies 10(4), 109-118 (2017)

4. B. Narteh, R. Odoom, M. Braimah, S. Buame, Key drivers of automobile brand choice in sub\#Saharan Africa: the case of Ghana, Journal of Product \& Brand Management 7, pp. 516 - 528. (2012).

5. G.M. Erickson, J.K. Johnsson, P. Chao, Image Variables in multi-attitude product evaluation; country-of-origin effects, Journal of Consumer Research 11, 649-99 (1984)

6. R. Gaedeke, Consumer attitudes toward products made in developing countries, Journal of Retailing 49, 13-24 (1973)

7. K. Thanasuta, T. Patoomsuwan, V. Chaimahawong, Y. Chiaravutthi, Brand and country of origin valuations of automobiles, Asia Pacific Journal of Marketing and Logistics 21, 355 - 375 (2009)

8. M. Montoya, Potentiality and Humanness: Revisiting the Anthropological Object in Contemporary Biomedicine. Current Anthropology 54, 45-55 (2013) 
9. Q. Ding, M. Akoorie, The characteristics and historical development path of the globalizing Chinese automobile industry, Journal of Technology Management in China 8,2, 83 - 104 (2013)

10. M. Přívarová, A. Př́ivara, Migration policy of Slovak Republic: issues and challenges. Actual Problems of Economics 10, 324-331 (2015)

11. M. Pitukhina, et al. Environmental aspects of circular migration study impact on "back up zones" development in the Russian Arctic microregion, International Journal of Ecology \& Development 32,3, 45-52 (2017)

12. A. Př́vara, Citizenship-for-Sale Schemes in Bulgaria, Cyprus, and Malta. Migration Letters 16,2, 245-254 (2019)

13. A. Abashidze, E. Trikoz, The ICC Statute and the Ratification Saga in the States of the Commonwealth of Independent States. International Humanitarian Law Series, 19, 1105-1110 (2009). 